\title{
De novo deletion of Xp22.2-pter in a female with linear skin lesions of the face and neck, microphthalmia, and anterior chamber eye anomalies
}

\author{
I K Temple, J A Hurst, S Hing, L Butler, M Baraitser
}

\begin{abstract}
A female infant is described with an unusual combination of eye and skin findings. Raw linear skin lesions on the face and neck were present at birth, healing to leave pigmented streaks. In addition she had left sided microphthalmia and bilateral sclerocornea. Chromosome analysis showed a terminal deletion of the short arm of the $X$ chromosome (Xp22.2-pter). Clinical findings were similar to three previously described children with translocations involving $\mathrm{Xp22.3}$. The condition probably represents a new syndrome distinct from incontinentia pigmenti and Goltz syndrome.
\end{abstract}

We describe a patient with a deletion of Xp22.2-pter with skin and eye changes distinct from incontinentia pigmenti (IP) and Goltz syndrome. Three cases have been reported by $\mathrm{Al}-\mathrm{Gazali}$ et al $^{\mathrm{1}}$ with a similar pattern of anomalies and disruption of $\mathrm{Xp22.3}$. Our case provides further evidence of a new syndrome.

\section{Case report}

The female proband was the first child of nonconsanguineous Nigerian parents aged 23 (mother) and 29 (father) years. She was born at term with a birth weight of $4500 \mathrm{~g}$ after a normal pregnancy and delivery. Raw linear lesions were noted at birth on the face and neck. They resembled scatches and did not

Department of Clinical Genetics, The Hospitals for Sick Children, Great Ormond Street, London WCIN 3JH.

I K Temple, J A Hurst, $M$ Baraitser

Department of Ophthalmology, The Hospitals for Sick Children, Great Ormond Street, London WCIN 3JH. S Hing

Department of Cytogenetics, Queen Elizabeth Hospital, Hackney Road, London E1.

L Butler

Correspondence to Dr Temple.

Received for publication 2 May 1989

Revised version accepted for publication 16 June 1989.

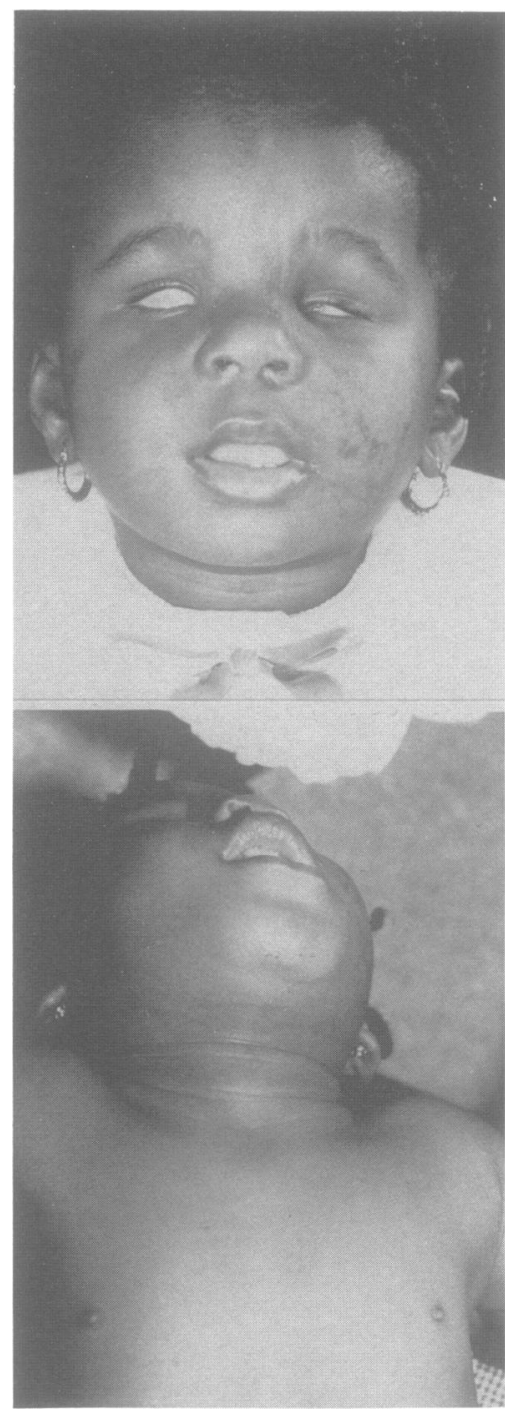

Figure 1 (Top) The proband aged 20 months showing linear pigmented streaks on the cheek and nose, bilateral sclerocormea, and left microphthalmia. (Bottom) Pigmented streaks on the neck. 
blister. The rest of the skin was normal. In addition, both eyes were swollen but left sided microphthalmia was suspected. By two months the skin lesions on the face healed to leave pigmented scars.

The proband presented to our genetic clinic aged 20 months when her mother was 28 weeks pregnant. Examination at that time showed healed but hyperpigmented linear scars on the face and neck (fig 1). One lesion extended onto the left shoulder, but the skin was otherwise normal apart from a small café au lait lesion on the trunk. Ophthalmological examination confirmed left microphthalmia associated with bilateral sclerocornęa. She had roving eye movements and vision was thought to be restricted to light perception only. Development appeared to be normal taking into consideration her visual handicap; she sat at six months, walked at 18 months, and had many single words.

Blood was taken for chromosome analysis. This showed a deletion of the terminal zone of the short arms of the $\mathrm{X}$ chromosome involving the region p22.2 to the telomere $(46, \mathrm{X}, \operatorname{del}(\mathrm{X})(\mathrm{p} 22.2$ - pter) (fig 2). Parental chromosomes were normal. The patient left the country before it was possible to look at her pattern of $\mathrm{X}$ inactivation.

\section{Discussion}

The differential diagnosis of this combination of asymmetrical skin and eye anomalies in a female child includes the syndromes of IP and Goltz. They are both multisystem disorders affecting structures of ectodermal and mesodermal origin and the inheritance is thought to be $\mathrm{X}$ linked dominant with lethality in males.

The skin lesions in IP classically progress from

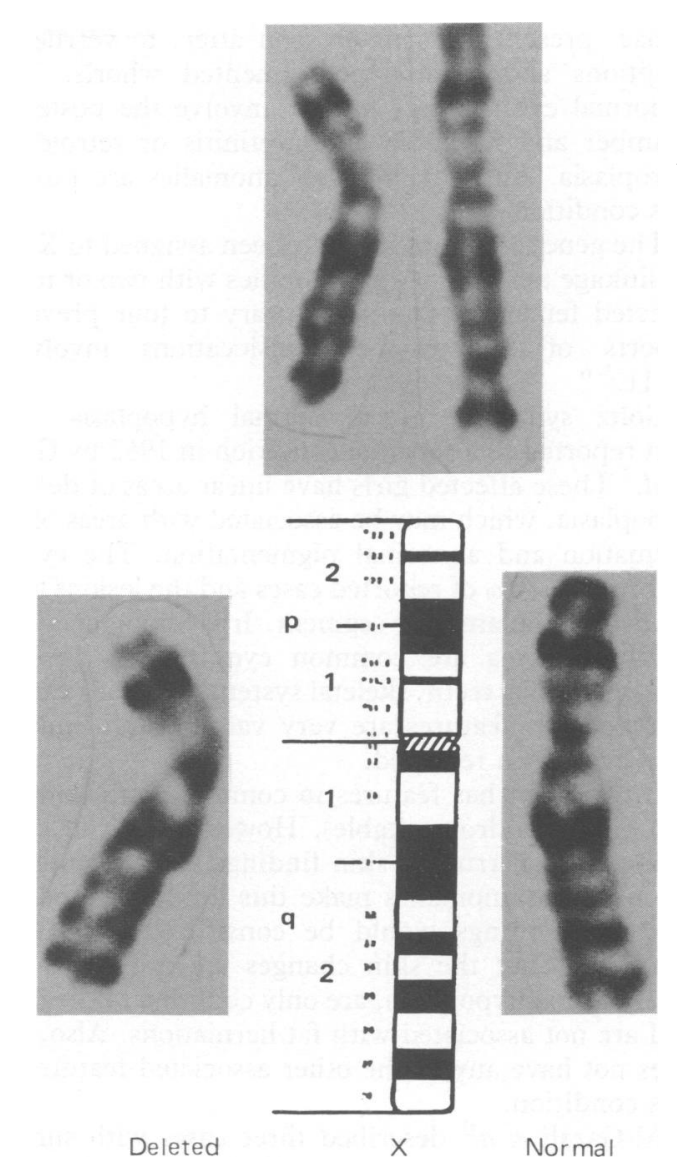

Figure 2 Pairs of $G$ banded $X$ chromosomes showing the extent of the short arm deletion of the $X$ (left) compared to the normal $X$ (right). The deletion involves Xp22.2-pter.

Comparison of features in our patient with those of IP and Goltz syndrome.

\begin{tabular}{llll}
\hline & \multicolumn{1}{c}{ Incontinentia pigmenti } & \multicolumn{1}{c}{ Goltz syndrome } & Xp22.2 deletion/disruption \\
\hline Skin & $\begin{array}{l}\text { Bullous lesions at birth over } \\
\text { any part of body. Later, } \\
\text { verrucous eruptions and } \\
\text { hyperpigmented whorls }\end{array}$ & $\begin{array}{l}\text { Linear dermal hypoplasia } \\
\text { with fat herniation }\end{array}$ & $\begin{array}{l}\text { Acute weeping linear lesions } \\
\text { on face and neck at birth. } \\
\text { Later, hyperpigmented streaks. }\end{array}$ \\
Eye & $\begin{array}{l}\text { Posterior chamber abnormalities, } \\
\text { 'chorioretinitis', } \\
\text { 'retrolental fibroplasia' }\end{array}$ & $\begin{array}{l}\text { Anterior chamber defects, } \\
\text { microphthalmia, } \\
\text { coloboma of iris }\end{array}$ & $\begin{array}{l}\text { Microphthalmia, sclerocornea, } \\
\text { orbital cysts }\end{array}$ \\
Teeth & Normal to anodontia & $\begin{array}{l}\text { Hypoplasia and abnormal } \\
\text { eruption pattern }\end{array}$ & Normal \\
Other & $\begin{array}{l}\text { Cleft lip and palate, } \\
\text { alopecia, syndactyly }\end{array}$ & $\begin{array}{l}\text { Diaphragmatic hernia, } \\
\text { exomphalos, } \\
\text { syndactyly/oligodactyly, } \\
\text { angiofibromata }\end{array}$ & - \\
Development & $\begin{array}{l}\text { Occasional mental retardation. } \\
\text { Usually normal development }\end{array}$ & Normal \\
Inheritance & $\begin{array}{l}\text { Xeizures, MR, hydrocephalus } \\
\text { mapped to Xq28 }\end{array}$ & $\begin{array}{l}\text { X linked dominant, } \\
\text { not mapped. }\end{array}$ & $\begin{array}{l}\text { ? X linked dominant. } \\
\text { Associated with deletion } \\
\text { involving Xp22-pter. }\end{array}$ \\
\hline
\end{tabular}


bullae, present at birth or soon after, to verrucous eruptions and later hyperpigmented whorls. The abnormal eye findings usually involve the posterior chamber and resemble chorioretinitis or retrolental fibroplasia. Anterior chamber anomalies are rare in this condition.

The gene for IP has recently been assigned to Xq28 by linkage analysis of eight familits with two or more affected females. ${ }^{2}$ This is contrary to four previous reports of $\mathrm{X}$;autosome translocations involving Xp11..$^{3-6}$

Goltz syndrome (focal dermal hypoplasia) was first reported as a separate condition in 1962 by Goltz et al. ${ }^{7}$ These affected girls have linear areas of dermal hypoplasia, which may be associated with areas of fat herniation and abnormal pigmentation. The eye is involved in $20 \%$ of reported cases and the lesions tend to involve the anterior segment. Iris colobomata and microphthalmia are common eye findings in this condition. The teeth, skeletal system, and nails can be involved but features are very variable. No linkage data have been reported.

Our patient has features in common with both IP and Goltz syndrome (table). However, lack of early bullous and verrucous skin findings and the anterior chamber eye anomalies make this unlikely to be IP. Her eye findings would be consistent with Goltz syndrome, but the skin changes are not typical of focal dermal hypoplasia, are only confined to the face, and are not associated with fat herniations. Also, she does not have any of the other associated features of this condition.

Al-Gazali et $a l^{1}$ described three cases with similar clinical features to our patient: irregular linear areas of erythematous skin hypoplasia involving the head and neck with microphthalmia, corneal opacities, and orbital cysts. All had normal development. Two of these patients were females with de novo $\mathrm{X} ; \mathrm{Y}$ translocations and the other case was a $46, \mathrm{XX}$ male in whom DNA studies indicated exchange of material between the short arms of the $\mathrm{X}$ and $\mathrm{Y}$ chromosomes. Cytogenetic analysis put the breakpoint on the $\mathrm{X}$ chromosome at $\mathrm{Xp22.3.}$

We consider that our patient has the same condition. We believe that it is probably distinct from IP and Goltz syndrome and represents a newly recognised combination of eye and skin findings owing to a disruption of a gene distal to Xp22.2.

1 Al-Gazali LI, Mueller RF, Caine A, et al. An XX male and two $t(X ; Y)$ females with linear skin defects and congenital microphthalmia: a new syndrome at Xp22.3. F Med Genet 1988;25: 638-9A.

2 Sefiani A, Abel L, Heuertz S, et al. The gene for incontinentia pigmenti is assigned to Xq28. Genomics 1989;4:427-9.

3 Hodgson SV, Neville B, Jones RWA, et al. Two cases of $\mathrm{X}$ /autosome translocations in females with incontinentia pigmenti. Hum Genet 1985;71:231-4.

4 Gilgenkrantz S, Tridon P, Pinet-Briquel N, Beurey I, Weber M. Translocation $(X ; 9)(\mathrm{pll} ; \mathrm{q} 34)$ in a girl with incontinentia pigmenti (IP); implications for the regional assignment of the IP locus to Xpl1? Ann Genet (Paris) 1985;28:90-2.

5 Kajii T, Tsukahara M, Fukushima Y, Hata A, Matuso K, Kuroki Y. Translocation $(\mathrm{X} ; 13)(\mathrm{pll} .21 ; \mathrm{q} 12.3)$ in a girl with incontinentia pigmenti and bilateral retinoblastoma. Ann Genet (Paris) 1985;28:219-23.

6 Cannizzarro LA, Hecht F. Gene for incontinentia pigmenti maps to band Xpll with an $(\mathrm{X} ; 10)(\mathrm{pl} 1 ; \mathrm{q} 22)$ translocation. Clin Genet 1987;32:66-9.

7 Goltz RW, Peterson WC, Gorlin RJ, et al. Focal dermal hypoplasia. Arch Dermatol 1962;86:708-17. 